\title{
Intermediaries and Capability Building in "Emerging" Clusters
}

Paper accepted by: Environment and Planning C: Government and Policy 32 (4). pp. 714-730

Full reference details:-

Clarke, Ian and Ramirez, Matias (2014) Intermediaries and capability building in 'emerging' clusters. Environment and Planning C: Government and Policy, 32 (4). pp. 714-730. ISSN 0263-774X (Print), 1472-3425 (Online) (doi:10.1068/c1262r)

Ian Clarke

Greenwich Business School

University of Greenwich

Old Royal Naval College

Park Row

Greenwich

London SE10 9LS

Email: I.Clarke@greenwich.ac.uk

Matias Ramirez (corresponding author)

SPRU - Science and Technology Policy Research

The Freeman Centre

University of Sussex

Brighton, BN1 9QE

UK

Email: matias.ramirez@ sussex.ac.uk

Phone: +44 2086456659

\begin{abstract}
Increasing attention has begun to focus on the important role organisations undertaking intermediary functions can play in supporting emerging clusters of small producers. In contrast to most studies of intermediaries that focus on governance and filling information gaps, in this paper we examine how the organisational skills of intermediaries evolve as firms in the cluster assume a broader range of practices. Through a purpose-built typology and a detailed case study, the argument is made that intermediaries act not only to facilitate the diffusion of knowledge, but that their scope of activities, extending into coordinating joint actions and new investment initiatives, places them at the centre of the network of organisations. This growing influence of intermediaries has implications for producer firms, especially in aspects such as inclusion of smaller producers and nework formation.
\end{abstract}

Key words: Intermediary, Cluster, Agriculture, Natural Resource 


\section{Introduction}

Policy makers in developing countries have been increasingly attracted to the new opportunities that have opened up for the upgrading of producer capabilities in some hitherto underdeveloped clusters (Gomes 2006; McCormick 1999). This has arisen principally as a consequence of the growing demand in industrial economies for natural resource-based commodities. Significantly, the labour intensive nature of production in some of these areas means that cluster growth is seen not only as means to improve the national balance of payments, but also a way to generate employment and improve the livelihoods of poorer farmers (Schmitz and Nadvi, 1999). Yet, it is also clear that the consolidation of these emerging clusters in export markets has been highly uneven across regions and sectors. Fragmented land ownership, poor communication infrastructure, unstable prices and above all the absence of lead producers with the resources to invest in new practices and technology create a low platform from which to develop producer capabilities.

With this in mind, attention has begun to focus on the important role organisations undertaking intermediary functions can play in supporting clusters of small producers. Intermediary organisations appear to have been particularly prominent in undertaking a range of activities associated to building what a section of the literature has called "collective efficiency", whereby joint actions by small firms facilitate upgrading of productive activities (Schmitz 1995; Gomes 2006; Schmitz and Nadvi 1999). This burgeoning area of literature raises some new questions for cluster dynamics, one of which is how do intermediary 
organisations develop the skills and competencies to support upgrading of producer capabilities? This is a particularly relevant area of research because in much of the cluster and regional dynamics literature, although intermediary organisations have been prominent in filling information gaps (Howells 2006) or assisting artisans and entrepreneurs respond to market opportunities (Piore and Sabel 1984), they have generally been consigned to playing a subsidiary role as compared to producer organisations. We, by contrast, suggest that in emerging cluster contexts, intermediaries can play a far more central role than has until now been recognized by the literature.

This paper therefore has a three-fold aim. Firstly to review and synthesize the literature of intermediary skills and roles, particular non-private intermediaries, in the development of emerging clusters (although our focus will be on non-private intermediaries, we also draw upon discussion of intermediary organisation more generally). Second, as part of this objective, to develop a taxonomy of intermediary activities in developing clusters. Lastly, to examine intermediary roles in clusters and operationalise the taxonomy through an in-depth empirical case study of an emerging cluster. From this work we draw some conclusions regarding how intermediaries develop skill sets and the influences these have on actors within clusters.

The contribution of the paper lies in two areas. Firstly, it provides a fuller understanding of non-private intermediaries by constructing a framework to understand the application of intermediary skills. This uses a "practice-based" approach (Brown and Duguid, 1991; Lave and Wenger 1991) that emphasises relational competencies and sees the advance of the whole cluster as the context for the development of specific intermediary skills. Secondly, we find that intermediary skills evolve in an interactive process through different stages in the cluster. Moreover, as the cluster develops new more complex practices, a small number of non-private 
intermediary organisations are propelled to the centre of the networks. These organisations have an important influence on the cluster, particularly in areas of inclusion, network formation and knowledge diffusion.

The paper is structured as follows. Firstly, we identify the context for the study of intermediaries by distinguishing the characteristics of "emerging" clusters. Second, we trace the theoretical and empirical literature of intermediary organisation roles in emerging clusters with a particular focus on the skill development of non-private intermediary organisations. As part of this discussion, a taxonomy of intermediary skills is presented in section 3 . In the methodology section we set out the research question, design of the social network analysis and case study format for the empirical analysis. Section 5 presents the network analysis results and highlights how intermediaries construct cluster networks. In section 6 we discuss the application of the taxonomy through semi structured interviews with cluster actors and specify key intermediary skills at different stages of the cluster. The final section reflects on the findings for the literature on intermediaries and clusters.

\section{Intermediation in "emerging" developing economy clusters}

Within advanced industrial economy contexts, clusters are habitually discussed with reference to agglomeration economies and in particular the advantages that accrue from greater competition, knowledge spillovers and concentration of skilled labour (Marshall 1920; Malmberg and Power 2005; Porter 1990). However, within a developmental context, clustering has taken a somewhat different narrative. Dominated in some cases by subsistence production, so-called "survival clusters" (Altenburg and Meyer-Stamer, 1999) have in the past been 
characterised by endemic underdevelopment (Amin 1994). The question posed in this paper is, given the new opportunities for export-led growth, what functions can intermediaries play as part of a new division of labour to encourage the upgrading of producer capabilities in these emerging clusters? We address this question by looking firstly at the challenges such clusters encounter.

Altenburg and Meyer-Stamer (1999) usefully differentiated clusters in less industrialized countries as a precursor to developing policy recommendations to generate positive externalities. The category of "survival cluster" refers to a cluster made up predominantly of micro and small-scale enterprises with poor entrepreneurial competence, a dearth of management skills, low trust and poor contract enforcement mechanisms which compromise the potential to reap the benefits of clustering. Although our use of the concept of emerging clusters differs from survival clusters in terms of their new found opportunities for exporting, they are clearly in a transitionary stage and inherit many of the structural problems associated with their past history. Thus, opportunities for penetrating export markets and adopting new productive capabilities through "learning-by-exporting" (Gereffi 1994), combine with the overwhelming dominance of small firms and micro enterprises that have few resources to invest in upgrading.

Yet, in their study of emerging clusters in the leather shoe clusters in Brazil, Schmitz (1995) and Sengenberger and Pyke (1991) argue that the problem facing small producers lies less in their size, than in their isolation and in some cases exclusion from opportunities for learning by larger established enterprises. The consequence, it is argued, is that small producers are often embedded in a social environment that is delinked from the business community of the formal sector, which creates obstacles to the diffusion of knowledge from the more modern 
firms. A second feature of survival clusters that may prevail has been found to be a general lack of trust between producers, and hence low willingness to cooperate. Altenburg and Gomez (1995) suggest that producers in survival clusters are particularly reluctant to share any kind of information because many owners perceive their business as a survival activity to sustain them until a better opportunity arises. In such an unstable environment there is little incentive to invest in long-term commitments and a good reputation.

Thirdly and perhaps most significantly, it is possible to distinguish a set of challenges stemming from the generalised absence of lead firms with the resources and know-how to invest in technological upgrading. Where lead firms exist, some of this knowledge can then diffuse to smaller firms through the supply chain or via coordinated efforts to disseminate knowledge. The absence of lead or anchor producer firms is critical and directly impinges upon our discussion of intermediaries. On the one hand, from the global value chain literature, much emphasis has been placed on the powerful role that buyers higher up the value chain have traditionally played in passing information to suppliers to assist in upgrading production capabilities (Gereffi 1994; Schmitz and Knorringa 2001). However, some case study evidence suggests that global buyer firms are not necessarily always prepared to assume this role. In her study of the fruit sector in Brazil, Gomes (2006) suggests a change in buyer behaviour has taken place in areas where product differentiation is less prominent, with greater responsibility for upgrading increasingly falling on local actors and less on firms further up the value chain. Buyers are increasingly in a position where they do not need to assist SMEs to meet the more demanding standards, as they have a choice of suppliers and can therefore select ones that currently comply with these standards. Apart from pointing the suppliers in the direction of relevant markets and establishing certification standards, buyers in some cases play very little 
role in the upgrading processes of local clusters. The hurdles and associated risks of meeting certification kitemarks, achieving consistent quality, organising logistics and establishing a basic scientific base for testing and measurement of quality standards therefore increasingly requires small-sized producers to build a local knowledge base with less reliance on global buyers and large firms (Schmitz and Nadvi 1999).

The literature around cluster dynamics has also emphasized that knowledge flows within 'cliques' of actors that tend to be larger firms with high absorptive capacity, can provide new knowledge inputs for smaller clustered firms (Giuliani and Bell, 2005). Yet, while many studies of successful developing clusters focus on the key role played by lead firms and their networks, the reality of emerging clusters is that they often lack lead firms with the resources to assume large-scale experimentation and risks. By contrast, there is greater reliance on coordinated action by groups of organisations, such as producer associations, that pool resources around training for the adoption of new practices. The concept of collective efficiency as developed by Schmitz (1995), whereby competitive advantage and upgrading can be derived from local external economies and joint action of small producers rather than requiring the prior existence of large firms is particularly relevant.

Upgrading of emerging clusters therefore involves above all developing the ability to access and in some cases adapt the most relevant knowledge for local producers and establish a basis for joint practices. Nevertheless, while the advantages of clusters in developmental contexts, including benefits derived from joint action, external economies and low transaction costs, continue to underline the potential advantages of co-location (Schmitz, 1995), it is also clear that for such benefits to emerge, a division of labour that enhances capabilities for learning and development also needs to emerge. It is in this context that some intermediary 
organisations have emerged to address key issues of inclusion, trust and communication in the process supporting the development of the cluster.

\section{Intermediaries and skills}

The previous section emphasized three principle challenges facing emerging clusters - lack of trust between actors, fragmentation and isolation of producers and thirdly poor producer competencies, caused in part by the absence of lead organisations in the context of fragmented global value chains. In this section, we critically discuss the main functions and roles of nonprivate intermediaries and how they relate to competence development in these clusters.

Research on intermediary contributions to building clusters is evident but fragmented. Much of it either provides a list of intermediary skills or describes the impact on other firms or communities of firms, without providing an explanation of how these skills were developed (Baruah 2010). Moreover, the contexts in which intermediaries function is extremely broad. Indeed, some studies have conceptualised intermediaries principally as taking advantage of monopoly rents on the information they have and control, without providing any value added themselves (Olson 1982, Popp 2000). However, an increasing number of studies see intermediary organisations as a vital component of a more complex division of labour, specialising in providing vital support services for various producers.

Given the range of uses of the term intermediaries, in this paper we refer to them as organisations that promote and facilitate knowledge flows between two or more parties, contributing to a process of learning and capability building amongst the firms and/or clusters with whom they work. From this definition it follows that a wide range of organisations, coming from public, not-for-profit and private sectors can potentially play intermediary roles. 
We begin by outlining two broad areas of study of intermediaries that are relevant to the support of producer firms. One focuses primarily on the supporting roles intermediaries provide to other firms by linking and facilitating the movement of information and knowledge. Howells (2006) suggests the burgeoning participation of intermediaries is indicative of a more complex organisation of activities in the knowledge economy. Collaboration, outsourcing and a more open innovation system has, he argues, led to a focus on the nodes and brokers through which knowledge transfers. Intermediaries therefore appear most commonly as a benign agent, mediating flows of knowledge between communities of actors. Their significance is therefore apparent undertaking numerous support roles including the reduction of information asymmetries (Popp 2000), supporting knowledge diffusion between communities (Bessant and Rush, 1995; Sapsed et al, 2007; Gherardi and Nicolini, 2002) and as brokers, strengthening existing links within communities (Burt 2005; Obstfeld 2005). Within this literature, the position of the intermediary between firms will be an important factor.

A second related area of work, emerging predominantly from detailed case studies of non-private intermediaries in developing economy clusters (NGOs, producer associations, government services) emphasizes the role of intermediation in helping to harness the collective action of groups or communities of actors. For example, Maggi (2003) and Pietrobelli and Rabellotti (2006) comment in relation to the development of the Chilean salmon industry that public bodies and international development cooperation agencies played a critical role in helping to establish common standards and gaining access to new markets for groups of firms. In her analysis of the same industry, Iizuka (2006) identifies how common institutions have been established for learning and negotiations, and how this has helped to enhance the collective capabilities within the industry to maintain international competitiveness. Giuliani et 
al (2005), Gomes (2006) and Schmitz and Nadvi (1999) have also commented on intermediary activities in helping to develop joint actions amongst small producers. This resonates with Schmitz and Nadvi's (1999) concept of collective efficiency, whereby consciously pursued collective actions can lead to local external economies. For these studies, the governance of intermediaries is likely to be central (McEvily and Zaheer 2004). This is firstly because private and non-private actors are likely to behave differently when deciding what collective activities to promote. Secondly, trust in intermediary organisations by cluster actors will differ according to the perceived motivation of the intermediaries (Bessant et al. 2003).

In this paper we introduce a third lens for the study of intermediaries, intermediary skills. A common factor underpinning most studies of intermediaries is that their skills are essentially relational. Therefore, beyond technical competencies and indeed governance, the influence of the intermediary is also likely to depend on the ability to understand, articulate and help develop new practices for producers. The following taxonomy explores this question in more detail. The focus on relational competencies leads us to adopt some of the principles provided by the "practice-based" literature (Lave and Wenger, 1991; Brown and Duguid, 2001). This emphasizes both how a social environment is created for the development of common practices (Amin and Roberts, 2008) and how "learning" can emerge from a process of knowledge transfer through the interaction between actors (Easterby-Smith et el 2008; Lave and Wenger 1991) within a community. In this perspective, practices form the centre-piece of learning, and because intermediaries help to create practice, they are not passive agents bridging information gaps. On the contrary, they intervene to create, prioritize and articulate meaning to these practices. 


\section{a. Accessing}

It is possible to group a set of activities associated with accessing knowledge. Examples of accessing knowledge can be found in a range of empirical studies. Maggi (2003) highlights accessing in the development of the Chilean salmon sector, while Bessant et al (2003) point to how the Industrial Restructuring Project (IRP) played an intermediary role by accessing important sources of knowledge that helped to bring the South African furniture industry international status and esteem. Accessing is also particularly associated with brokering activities (Hargadon 1998, Burt 2005). For Burt (2005) in particular, intermediaries can play a significant role in networks by filling gaps in the structure of information flows between actors - so-called structural holes. Intermediaries can therefore prosper where there are opportunities for "closure", in other words, filling voids and connecting otherwise separated communities. There is some debate as to the circumstances in which intermediaries may limit their search strategies to vertical ties. Vertical ties can help to maintain dense ties that can restrict network variety, as opposed to encouraging broader ties through horizontal search strategies amongst a variety of stakeholder groups (Safford 2007, Zuckerman and Sgourev 2006). The choices may depend on the integrative abilities (Easterby-Smith et al 2008) of the intermediary to understand the needs of actors inside the cluster and assess the value of different alternatives, or indeed prioritise these alternatives.

\section{b. Diffusion}

A second group of intermediary activities can be grouped around the concept of diffusion and refers to the spread of knowledge amongst different actors within a community of practitioners. 
Empirically, diffusion activities have for example been identified by Bessant and Rush (1995), who discuss how consultants fulfil, either implicitly or explicitly, the function of experience sharing. Their role in this context is compared to that of bees, as they cross-pollinate between firms and carry experiences and ideas from one location to another. Intermediaries are also important in setting up both infrastructures and relevant spaces that diffusion of knowledge require. Thus, trade associations often host websites, distribute newsletters and arrange physical and pre-arranged events, such as trade conferences, that become ritualistic spaces where new practices and strategies can be legitimized. On the other hand, the formal skills required for diffusion include the ability to communicate effectively and to build and maintain a network of organisations. Here, the centrality of the intermediary within the network, which may depend on both formal roles (for example a dominant trade association) or on access to knowledge, will be crucial.

An important aspect of this discussion concerns the influence intermediaries can wield when diffusing certain practices. For example, Giuliani (2003) defined oenologists in the Chilean wine cluster as an epistemic community who share a technical language and scientific background. Amongst themselves they developed a common understanding of a specific set of problems that were passed on to producers. However, the diffusion of a new practice can lead to exclusion, loss of synchronization (Brown and Duguid 2001) and can be contested, as shown in Provan and Human's (1999) study of brokers within US SME wood-processing firms. Here brokers needed to make choices between centralizing information or encouraging dispersed communication amongst the actors. Where the broker encouraged less reliance on itself, this led to a more productive environment for learning to take place (ibid.). The agency role of the broker is clearly magnified in terms of the influence on learning outcomes. 


\section{c. Coordination}

A third skill function performed by intermediary organisations is that of coordination, a challenging task where firms are often unstable and have few resources to take on risky investments or where there is a lack of trust or cooperation amongst producers. Combining trust with specialised intermediary skills is evident in Bessant et al's (2003) study of the South African furniture industry. On the one hand, intermediaries worked closely with internal change agents to produce what Brown and Duguid (2001) have called "boundary objects" (shared documents, tools, processes, schedules). On the other hand, a key factor mentioned for the success of the intermediaries was that they were seen by the parties as not favouring some firms over others, which can be a particularly important feature of traditional power dynamics within certain industries. In these circumstances, a specialised division of labour for coordination in the form of an intermediary proved to be highly valuable.

Coordination roles can also encompass the formulation and assistance for the implementation of common strategies amongst the members of a cluster. For example, Gomes (2006) comments on the important role played by the Brazilian Apple Growers Association and EPAGRI (the state's Agricultural and Research Agency) in the cluster-wide upgrading efforts of three fresh fruit producing clusters in Brazil. The intermediary role in helping small growers organise into cooperatives that enabled growers to process and market their apples collectively was highlighted. In these cases, strategizing is based on a longer-term relationship between the intermediary organisation and the parties with whom they are working. 


\section{d. Enabling}

The fourth and most challenging intermediary role identified in the literature is that of enabling. For enabling roles to be carried out, intermediaries require research facilities and infrastructure and/or human resources necessary to achieve a designed innovation, available either in-house or at least easily accessible.

There are two parts to this role, firstly providing new knowledge inputs and secondly adapting existing knowledge to make it applicable to a different context and situation. Through his empirical study, Howells (2006) makes the point that many of the intermediary tasks initially limited themselves to matchmaking and brokering (accessing). However, as these intermediaries learned and improved their competence, they moved out of these initial roles and assumed wider and more complex functions. For example, organisations involved in formal testing, accreditation or standard setting began to develop these roles independently, in part because they were able to facilitate interaction with outside knowledge much more easily and because for clients, intermediary organisations are seen as being independent and impartial by supplier and user firms alike.

The second part of the enabling role is that of adapting knowledge and making it applicable to a new situation. This role relates closely to the role of translation. Brown and Duguid (1998) described translators as actors able to frame the interest of one community in terms of another community's perspective so that they are mutually intelligible. Translation is useful for understanding how communication can be facilitated in such cases because communities have different standards, priorities and evaluating criteria. Thus, in a study in the

Colchagua Valley wine cluster in Chile, disagreements occurred between professional 
winemakers, whose main focus was on quality and entrepreneurs whose main focus was on profits. This required the development of common interests (Hojman, 2005).

\section{Research questions and methodology}

The previous discussion outlined a taxonomy of intermediaries functions (accessing, diffusing, coordination, enabling) associated with specific skills and competencies. However, as outlined earlier, the application of these needs to be understood within the specific context of two other factors; the position of the intermediaries in the cluster (on the margins or at the centre) and the governance of the intermediary. With this in mind, sections 5 and 6 outline the results of an investigation into the development of intermediary skills and the influence of intermediaries on producer firms in the cluster.

The empirical study consists of a detailed case study undertaken of the Piura mango cluster in Northern Peru. It is one of the country's most important emerging agricultural export regions, although export of mangos only really began to increase in the 1990s when the first hot water treatment plant was installed. The area is able to take advantage of unique dry tropical weather conditions, which allow rapid growth of crops without the associated problems of excess rainfall (Ginocchio, 1993). This helped to confirm Piura as the region with the most important mango producing department in the country, contributing to $3 \%$ of non-traditional exports for Peru in 2008.

In contrast to some other successful export clusters of Peru, such as Asparagus, in Piura there is no large dominant firm, although there is a division between larger firms that produce and export and smaller producers that export only. This division is reflected in the two producer 
associations, APEM, which represents organisations combining exporting and production and PROMANGO, which represents smaller producers only. These two organisations form the centre-piece of this study. Small enterprises and micro producers generally sell their produce to the larger firms that have the technology to treat the mangos before they are exported.

The question posed by this research is how intermediary organisations develop the skills and competencies to support producer organisations in emerging clusters and how does the development of intermediary skills influence cluster actors. We examine this question in two stages. Firstly, given the importance attributed to the intermediary in accessing and distributing knowledge, we analyse the network structure of the cluster through its knowledge flows and the position of the intermediaries within this. For this purpose, a face-to-face survey with 26 organisations belonging to the producer associations APEM and PROMANGO and eight significant intermediaries was carried out. The question in this survey was: "from whom did your organisation (or business) receive technical and commercial assistance and how important was this to your organisation"? Respondents were then provided a list of organisations (producers, services, universities, consultancies) and an open section to name other organisations from whom assistance had been received and to then identify and rank organisations from whom knowledge was received from 1-5 in ascending order of importance. From this information it was possible to produce a network map using open source social network analysis software "PAJEK", showing the ego centric relations (i.e. the ties between two organisations) based on the movement of knowledge between organisations (see figure 1 below). This section provides an indication of the centrality of intermediaries and their influence on knowledge transfer in the cluster. 
The second part of the analysis consisted of semi-structured interviews that provide richer detail of the nature of intermediary skills. These were analysed primarily through the lens provided by the taxonomy of intermediary practices presented in section 4. Specific question were also asked of intermediaries on its role as an intermediary, knowledge transfer, receiving knowledge from inside and outside the cluster and sources of information.

Following the approach that, amongst other issues, emphasized the building of joint practices, we would expect intermediary skill development to be to some degree both a product and function of the cluster community and would co-evolve with the development of the cluster.

Twenty semi-structured interviews took place with owners of small and medium sized mango firms and with directors of the main intermediaries including APEM, PROMANGO and several government agencies with offices located in Piura. Finally, the producer association congresses of APEM and PROMANGO were attended and detailed notes made as participant observers. The three sources of data gathering allowed corroboration of the formal structures of the cluster and data to be gathered from the main institutional actors in the cluster. Below we also provide a list of non-private intermediary organisations discussed in this paper. 


\section{Table 1 Details of main mango cluster intermediaries}

\begin{tabular}{|l|l|l|}
\hline Name of Organisation & Type of Organisation & Brief description of role \\
\hline Apem & Trade Association & Works with producers, processors and exporters. \\
\hline Promango & Trade Association & Works with medium sized producers. \\
\hline Promperu & Promotional Body & Promotes Peruvian exports. \\
\hline Senasa & Phytosanitary Body & Monitors food safety. \\
\hline Inia & Research Body & Encourages agricultural research \\
& & \\
\hline
\end{tabular}

Source: author compilation

\section{Cluster characteristics}

The opening of Western markets to exports of fresh fruit and especially mangos provided the community of producers from Piura with a strong incentive to coordinate supply strategies both to improve the quality of produce along the supply chain and avoid large fluctuations in price ${ }^{\mathrm{i}}$. This forced local growers to address a history of mistrust and tensions. Larger firms traditionally claimed the quality of produce from small producers was poor, while smaller firms claimed exporters act as cartels to fix prices and delay payment. Consequently, at least in some sections of the industry, more stable relationships between producers and exporters began to emerge, including Sunshine's (the largest local exporter firm) initiative to organize a training programme, with government funds, for its SME suppliers to gain skills to obtain accreditation for exports. And yet, the data from the survey actually suggests that no one individual mango producer or exporter is considered by their peers to be a major provider of knowledge transfer or source of 
inter-firm links. This can be measured in two ways. Diagrammatically, the network algorithm puts the organisations with the highest number of links at the centre of the network, thus allowing a graphical representation of the most important brokers in the organisation. In figure 1, the producer organisations are represented by vertices and labelled by pseudo name agro 1 to agro 26 and by colour. Service organisations undertaking intermediary functions are coloured red; larger producers that also export and are members of the association APEM are brown; smaller producer organisations members of PROMANGO are grey. This shows that the organisations at the very centre of the knowledge flows in the cluster, i.e. those with most inflows and outflows of knowledge, are the producer associations APEM and PROMANGO, and the government services offices SENASA, INCAGRO and PROMPERU. It also shows that producers are structurally divided between the two associations, larger producers and exporters clustered around APEM and smaller producers clustered around PROMANGO. 
Figure 1: Social Network Analysis of Piuran Mango Cluster

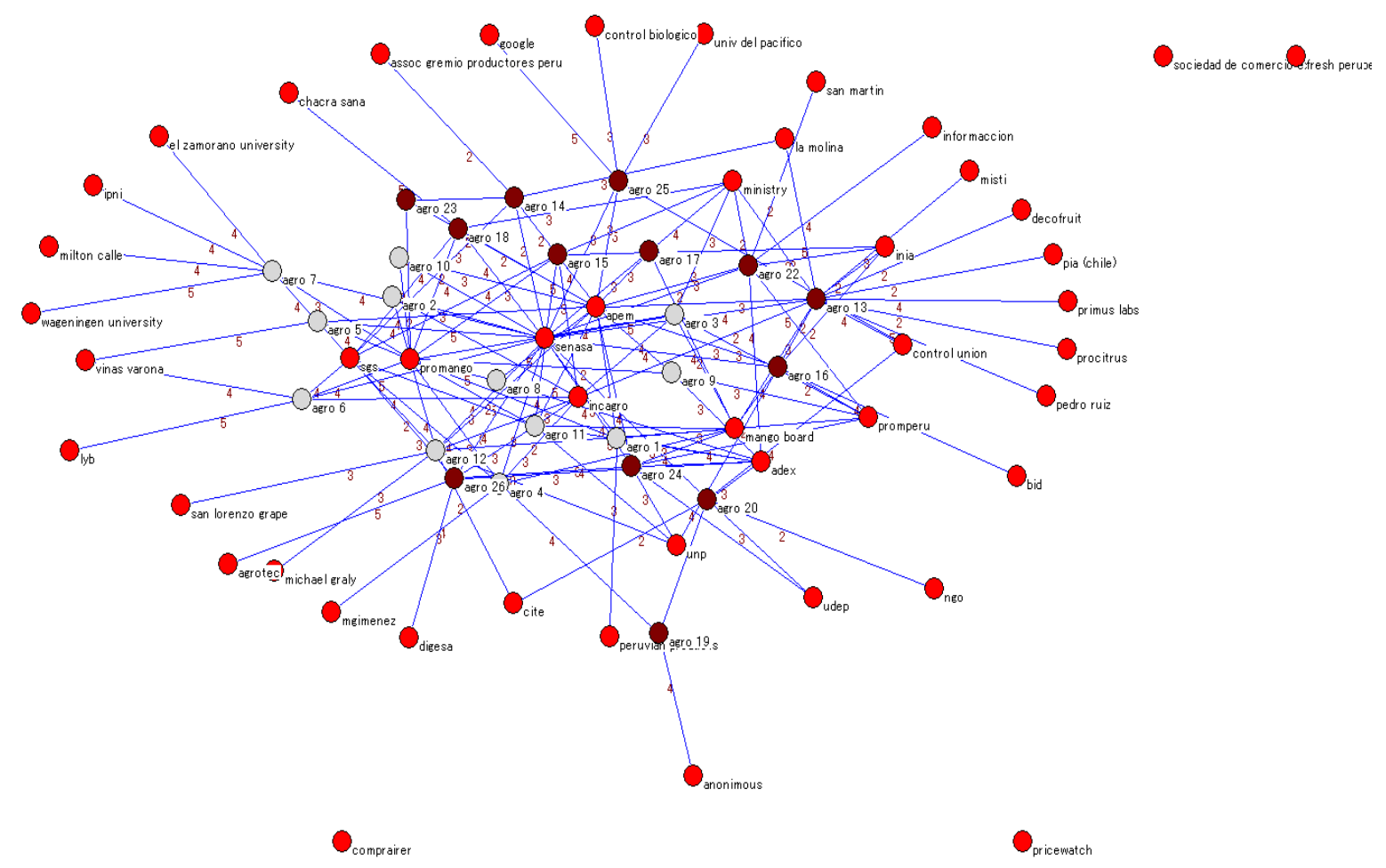

Source: Derived from survey of cluster organisations

The map suggests a cluster where organisations are highly linked. Nevertheless, a more detailed visualisation of knowledge transfer just between mango producer organisations in figure 2 below, actually shows that there is very little transfer of knowledge directly between these organisations, especially within members of PROMANGO. However, when APEM and PROMANGO are included, these organisations in effect become linked, through the 
associations. Through this process, producer organisations position themselves at the very centre of producers in a hub and spoke structure.

Figure 2: Social network analysis of Piruran mango cluster of producer organisations and associations

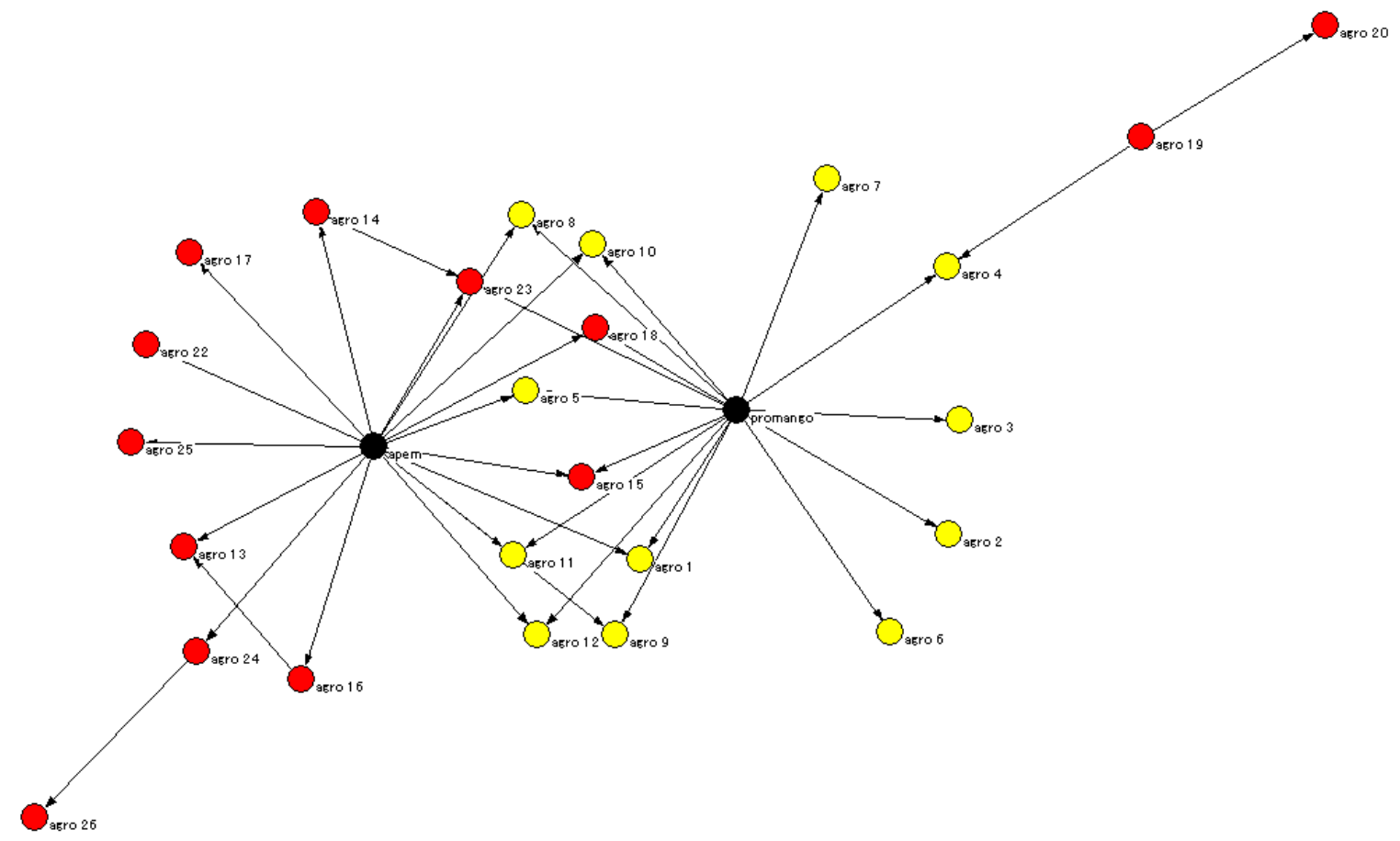

Source: Derived from survey of cluster organisations

The strong influence of intermediaries can also be measured by calculating the degree centrality statistic in table 2. This is defined as the number of ties incident upon a node or the number of paths of length that emanate from a node (Everett and Borgatti, 2005). It is therefore a relatively basic measure of the number of links each actor has in the network. It shows that of the 15 
organisations with most outlinks, the top three organisations are the intermediaries APEM and PROMANGO, and the phytosanitary organisation SENASA. Moreover, the principle providers of knowledge appear to be consultancies, government services and universities. Only one mango producer organisation was mentioned in the top 15 knowledge providers.

Table 2: Degree Centrality of organisations in the Mango Cluster

\begin{tabular}{|c|c|c|}
\hline $\begin{array}{l}\text { Weighted } \\
\text { average out } \\
\text { degree } \\
\text { centrality } \\
\end{array}$ & Organisation & $\begin{array}{l}\text { Type of } \\
\text { Organisation }\end{array}$ \\
\hline 8 & Agro 19 & $\begin{array}{l}\text { Mango } \\
\text { Producer }\end{array}$ \\
\hline 8 & La Molina & University \\
\hline 9 & Vinas Varona & $\begin{array}{l}\text { Private } \\
\text { consultant }\end{array}$ \\
\hline 11 & Control Union & $\begin{array}{l}\text { Certification } \\
\text { Organisation } \\
\end{array}$ \\
\hline 11 & $\begin{array}{l}\text { Instituto } \\
\text { Nacional de } \\
\text { Innovación } \\
\text { Agraria }\end{array}$ & $\begin{array}{l}\text { Government } \\
\text { Service }\end{array}$ \\
\hline 16 & UNP & University \\
\hline 23 & $\begin{array}{l}\text { Ministry of } \\
\text { Agriculture }\end{array}$ & $\begin{array}{l}\text { Government } \\
\text { Service }\end{array}$ \\
\hline 23 & PROMPERU & $\begin{array}{l}\text { Government } \\
\text { Service }\end{array}$ \\
\hline 26 & Mango Board & $\begin{array}{l}\text { Overseas } \\
\text { Industry } \\
\text { Association } \\
\text { (US) } \\
\end{array}$ \\
\hline 27 & INCAGRO & $\begin{array}{l}\text { Government } \\
\text { Service }\end{array}$ \\
\hline 32 & SGS & $\begin{array}{l}\text { Certification } \\
\text { Organisation } \\
\end{array}$ \\
\hline 33 & ADEX & $\begin{array}{l}\text { Government } \\
\text { Service }\end{array}$ \\
\hline 55 & PROMANGO & $\begin{array}{l}\text { Local Industry } \\
\text { Association }\end{array}$ \\
\hline 57 & APEM & $\begin{array}{l}\text { Local Industry } \\
\text { Association }\end{array}$ \\
\hline 77 & SENASA & $\begin{array}{l}\text { Government } \\
\text { Service }\end{array}$ \\
\hline
\end{tabular}


A second feature we highlight is the role that intermediaries, and in particular PROMANGO, play in bringing outside knowledge into the cluster and diffusing this to other organisations. Table 3 shows the sources of knowledge inflows into PROMANGO and the technical and commercial importance of these, as rated by representatives of PROMANGO (where the importance of knowledge inflow from an organisation is attributed values 1 to 5 , least to most important). The table below illustrates that PROMANGO accesses commercially relevant knowledge from neighbouring countries Brazil and Ecuador. It also has very important relationships with two universities that are relevant for technological knowledge. Table 4 on the other hand shows the sources of knowledge of PROMANGO firms (i.e members of the association). This shows producer firms receive knowledge from a narrower group of service and intermediary firms, virtually all intermediaries located inside the cluster. PROMANGO is in effect the unique contact point for PROMANGO members for both universities and a number of overseas firms. As the knowledge received is more technologically complex and developed in a different context, it is translated by the association and through its congresses and other events, diffused to its members, making the knowledge collective. This contrasts with knowledge received by firms such as agro 8 and 25, who do not share this knowledge. In this case, the knowledge is private. 
Table 3 Promango: Sources of Knowledge

\begin{tabular}{|l|l|l|}
\hline Knowledge Source & $\begin{array}{l}\text { Technological Knowledge } \\
\text { Received (Importance 1-5) }\end{array}$ & $\begin{array}{l}\text { Commercial knowledge received } \\
\text { (Importance 1-5) }\end{array}$ \\
\hline EMBRAPA (Brazil) & 5 & 1 \\
\hline GlobalGap & 5 & 1 \\
\hline Pivano (Ecuador) & 5 & 3 \\
\hline Senasa & 4 & 0 \\
\hline INIA & 3 & 0 \\
\hline CITE & 2 & 0 \\
\hline UDEP (University) & 2 & 0 \\
\hline UNP (University) & 2 & 0 \\
\hline Promperu & 0 & 2 \\
\hline National Mango Board (USA) & 0 & 2 \\
\hline
\end{tabular}

(Source: Intermediary survey)

Table 4 Promango Member Firms: Sources of Technological Knowledge

\begin{tabular}{|l|l|l|}
\hline $\begin{array}{l}\text { Name of Intermediary } \\
\text { Organisation }\end{array}$ & $\begin{array}{l}\text { No. of firms identifying } \\
\text { organisation as source of } \\
\text { technological knowledge }\end{array}$ & $\begin{array}{l}\text { Firm ranking of importance of } \\
\text { knowledge received } \begin{array}{r}\text { (average } \\
\text { calculated from scale: 1 little } \\
\text { importance, 5 = very important) }\end{array}\end{array}$ \\
\hline Promango & 12 & 3.6 \\
\hline Senasa & 11 & 2.5 \\
\hline APEM & 9 & 2.6 \\
\hline Incagro & 7 & 2.5 \\
\hline Adex & 6 & 1.4 \\
\hline Promperu & 6 & 2.2 \\
\hline INIA & 5 & 1 \\
\hline National Mango Board (USA) & 5 & 3.4 \\
\hline SGS (Certification Firm) & 5 & 3.3 \\
\hline
\end{tabular}

(Source: Firm Survey) 


\section{Phases of Intermediary and Clusters Development}

\section{$1^{\text {st }}$ phase: Accessing and bridging information gaps}

This section provides a qualitative analysis of the skills and competencies developed by intermediaries within the mango cluster through the different stages of its development. It is possible to identify three principle intermediary activities in the early exporting phase of the mango. The first is provision of information for producers, the second establishing joint practices and the third incorporating new knowledge from outside the cluster. As discussed, two communities of firms are examined in this study- those that produce and export, and smaller sized producers only- that function in a similar space but with overlapping and different priorities and values. The importance and functions of intermediaries within each of these groups therefore also varies significantly.

Taking firstly the case of the exporter firms, APEM's "business community" values emphasize opening export markets, therefore its primary requirement was to bridge the information gap of producers. APEM provided a shared resource for understanding how the export market functions, including certification requirements and the needs of retailers predominantly supermarkets. Other intermediaries developed similar search skills that bridged the information gap between producers and overseas buyers. PROMPERU for example, developed a comprehensive knowledge base for producers to contact buyers by organizing trips by potential exporters to destination markets.

Smaller-sized growers on the other hand faced a different set of information-related problems. Many producer practices had hitherto developed in isolation with little sharing or effort to develop or diffuse best practices. The low price that traditionally can be charged in 
domestic markets meant producer horizons tended to be short-term and there has been little incentive to methodically improve production, invest in technologies or share good-practice.

Following the opportunities opened by new export markets, PROMANGO established a community of practice. Yet, unlike APEM's business gravitas, the community of growers around PROMANGO resemble Amin and Cohendet's (2004) concept of a craft community, where there are limits to codification. Learning occurs through watching and imitating and new competencies develop from existing practices. PROMANGO's initial bridging efforts therefore was as a broker, encouraging producers to communicate, comparing experiences and establishing a common identity based on sharing good practices. Formal events such as the annual PROMANGO congress, specific training programmes and informal gatherings with the explicit purpose of revealing best practice were organised and created ritual spaces in which best practices could be shared.

The need to access new information in these early stages therefore gave rise to different intermediary skills. Through its bridging role, PROMANGO constructed networks by providing greater transparency to the cluster and identifying shared interests. These interests very quickly became agendas around which joint practices could be initiated. These activities soon propelled the intermediary into assuming an important leadership role.

As demonstrated earlier, the central role of intermediaries in the cluster was magnified when analysing their role in establishing contact with organisations outside the cluster. International speakers were invited to APEM and PROMANGO congresses, where key challenges, such as diversification of production to different mango types or establishing new export routes to China were discussed. PROMANGO and its meetings become the space at 
which other organisations and in particular SENASA, the phytosanitary organisation, disseminated its advice, norms and regulations on critical issues such as preventative measures to keep the fruit fly out of the area. APEM and PROMANGO therefore become the focal point through which information by producers and other service organisations was concentrated and then disseminated.

\section{$2^{\text {nd }}$ phase: Coordinating and creating new practices}

A second phase of activities that emerged some years after the mango cluster began exporting involved intermediaries coordinating projects to establish joint practices between members of adjoining communities (for example between producers and exporters or firms and scientists). This reflects a more complex set of activities compared to the earlier phase, requiring skills such as integrating various groups with different disciplines and motivations. For example, a substantial initiative coordinated by APEM was the establishment of a standards committee for the implementation of new industry norms to improve the quality of fresh mango. The committee was conformed by government agencies, universities and organisations from outside the cluster. It thus served as a meeting point around which traditional business concerns and scientific and food safety specialists congregated.

The production of a technical standards document was a significant step for the cluster and chimes with Brown and Duguid's (1998) point that "boundary objects" can help to make a community's pre-suppositions apparent to itself, thereby encouraging a process of reflection and development of joint practices. APEM's role was to promote a shared understanding and

reach a consensus of agreed common steps. In this process, APEM moved from provider of 
information, into the realm of agenda setting and establishing strategic priorities for its members.

Greater coordination was intimately associated to the intermediary role in building trust between itself and producer organisations. This was underlined in a significant coordination activity that involved a set of training activities to facilitate the certification of small and medium sized producers. Intermediation was essential because of the history of mistrust between producer SMEs who sell their fruit to the larger exporter firms. Trust was facilitated because, in essence, as a third party player and network facilitator, APEM's narrative was based on highlighting the mutually beneficial opportunities for adopting new practices and creating the conditions for collective action. The role of the intermediary as an agent deliberately designing and constructing trust within a cluster is also emphasized by McEvily and Zaheer (2004), who showed that brokers can build trust because of the social capital they establish as a consequence of working with different actors. Thus, new skills and structural positioning in the cluster go hand in hand. Through their central positioning in the cluster, intermediaries have the facility to gather the information to facilitate the production of objects and documents that codify important practices. This position also provides the contacts and relationships necessary to establish relationships in this process.

\section{$3^{\text {rd }}$ phase: Enabling and development of new knowledge}

A third phase of intermediary activity identified, focused on developing new knowledge for the cluster. Two types of contributions can be recognized. The first is predominantly technical and is aimed at enhancing production capabilities inside the cluster. The activities of 
the phytosanitary organisation SENASA are relevant here. SENASA established local offices and their work was repeatedly praised by exporting firms for their ability to translate complex norms and regulations to the needs of local producers. This includes the establishment of a hot water treatment procedure for exports to Japan, where the treatment criteria for fruit differs to other parts of the world. This experience contrasts somewhat with that of INIA, the national institute for agrarian innovation, with whom PROMANGO representatives expressed mixed feelings. The principle critique was that it was too slow to act when assistance was required and its limited local know-how, which was blamed on the absence of a local office in Piura. Clearly investment in relational knowledge and presence in the area is relevant in technical as well as coordinating roles.

A second enabling contribution relied less on technical skills than on organisational knowledge of the cluster. A new strategic initiative to enter the Chinese and Japanese markets led by APEM was particular significant. It worked with a group of firms to establish a set of common objectives whilst minimizing the financial risks to individual firms. APEM not only initiated the project, but undertook the necessary studies of logistics adequate for the cluster and contacts in China to make the new strategy a viable enterprise. An added significance of the intermediary leadership is that while only a few firms initially pioneered exporting to China, the benefits of such activity could potentially be shared amongst association members, who can use APEM contacts to establish their own clients. This initiative emphasizes how intermediaries are able to reduce the risk inherent in implementing new production initiatives. The intermediary helped to select organisations that would be more able to assume the initial risk of opening markets to the Far East, while providing logistical backup required for such an initiative. 


\section{Discussion and conclusions}

This study builds on existing evidence that intermediaries are playing an increasingly important role in clusters, particularly where coordination and diffusion of new practices is concerned. However, unlike many cluster studies that see intermediary type organisations as important but secondary actors, the network analysis illustrates a hub and spoke structure with the intermediary at its centre. The significance of this finding is two-fold. Firstly, intermediary organisations provided a unique bridge for otherwise disconnected organisations. McEvily and Zaheer (2004) refer to intermediaries as network facilitators, in our study they resemble network constructors, as well as facilitators. Secondly, intermediaries, and in particular the producer associations, were the unique contact point for many key outside organisations. However, unlike some private firms, intermediaries had an inclusive agenda, sharing rather than hoarding this knowledge. Studies of clusters in different industrial settings suggest hub and spoke or star structures are typically able to rapidly diffuse information and generate rapid regional growth (Gray et al. 1996; Olson 1982). This feature may help explain the Piuran mango cluster's rapid growth in production in its early phase.

Although this suggests intermediaries can be anchor organisations for other disconnected firms, it nevertheless leaves a hanging question mark regarding what makes an effective intermediary? This is a relevant question given that this research and other work by for example Pant et al (2008), has also highlighted some poorly performing intermediaries. Moreover Burt (2005) emphasizes that intermediaries can take advantage of their monopoly 
position to extract rent. For some important studies, the distinguishing feature influencing intermediary effectiveness lies in its governance. For example as a third party, an intermediary can engineer the trust of producer organisations to maximize economic success (McEvily and Zaheer, 2004), the fact that it is often more transparent and open to scrutiny helps this process (Kohl 2003). For McDermott (2009) on the other hand, the public-private status of some intermediaries encourages them to access diverse knowledge from outside the cluster, allowing broad rather than narrow networks to be built.

And yet, this paper suggests that intermediaries assumed a benign anchor role not merely through governance design but also through an evolving process of interactive learning and skill development. Intermediary skills are essentially relational and the discussion suggested these co-evolved through different stages of cluster development; from passive bridges to evaluating the benefits of outside technologies to project management of joint actions and coordination strategies. The social capital built up by some intermediaries at the centre of the network helped in this process by providing a broader overarching perspective than that afforded to any one firm. Moreover the creation of physical and nonphysical meeting spaces (bulletins, websites, conferences) provided producers a forum that made networks denser and more inclusive. As we have argued, these experiences facilitated specific skills associated to learning how to find common ground between actors. We argue that these activities represent an important division of labour for this emerging cluster and in this process, helped to define the cluster's social context.

In terms of further studies, this paper raises many more questions regarding the strengths, but also the limits of intermediary activity as leading organisations in clusters. The study suggests that the strong state support in the form of finance and an ecosystem of 
supporting services are essential. Although a study of this question was beyond the remit of this study, Baruah (2010) has argued it will affect the influence of intermediaries. A second agenda for the study is to look at clusters in more advanced stages of development in emerging countries. This might be beneficial since some studies, for example Schmitz and Nadvi (1999), suggest that achieving collaboration between firms in functions other than enhancing producer competencies, for example marketing and branding, may be more complex and challenging.

Acknowledgments The authors would like to thank the British Academy for their support in the research presented in this paper. We would also like to pay special thanks to the representatives of APEM and PROMANGO producer associations for their time and allowing us to interview their member firms. 


\section{References}

Altenburg T, Meyer-Stamer, J, 1999, "How to Promote Clusters: Policy Experiences from Latin America" World Development 27 1693-1713

Altenburg T, Gomez R, 1995, “La pequeña y microempresa manufacturera en Costa Rica y Honduras: refugio de los marginados o semillero de la reindustrialización?", in Apertura comercial en Centroamérica: nuevos retos para la industria Eds T Altenburg, H. Nuhn, (DEI, San Jose) pp 191-222

Amin A, Cohendet P, 2004 Architectures of Knowledge: Firms, Capabilities and Communities (Oxford University Press, Oxford)

Amin A, Roberts J, 2008, "Knowing in Action: Beyond Communities of Practice" Research Policy 37 353-369

Baruah, B, 2010, "Energy services for the urban poor: NGO participation in slum electrification in India” Environment and Planning C: Government and Policy 28 1011-1027

Bessant J, Rush H, 1995, "Building Bridges for Innovation: The Role of Consultants in Technology Transfer” Research Policy 24 97-114

Bessant J, Kaplinsky R, Morris M, 2003, "Developing capability through learning networks" International Journal of Technology Management and Sustainable Development 2 19-38

Brown JS, Duguid P, 1991. “Organisational Learning and Communities-of-Practice: Towards a Unified View of Working, Learning and Innovation” Organisation Science 2 40-57

Brown JS, Duguid, P, 1998, “Organizing Knowledge” California Management Review 40 90111 
Brown JS, Duguid P, 2001, "Knowledge and Organization: A Social-Practice Perspective", Organization Science 12, 198-221

Burt RS, 2005 Brokerage and Closure: An Introduction to Social Capital (Oxford University Press, Oxford)

Easterby-Smith M, Lyles ML, Tsang EWK, 2008, “Inter-Organizational Knowledge Transfer: Current Themes and Future Prospects” Journal of Management Studies 45 677690

Everett MG, Borgatti SP, 2005, "Extending Centrality", in Models and Methods in Social Network Analys Eds PJ Carrington, J Scott, S Wasserman (Cambridge University Press, Cambridge) pp 57-76

Gereffi G, 1994, “The Organisation of Buyer-Driven Global Commodity Chains: How the US Retailers Shape Overseas Production Networks" in Commodity Chains and Global Capitalism, Eds G Gereffi, M Korzeniewicz (Praeger, Westport, C.T) pp 95-122

Gherardi S, Nicolini D, 2002, "Learning in a Constellation of Interconnected Practices: Canon or Dissonance” Journal of Management Practices 39, 419-436

Ginocchio L, 1993 Agroindustria (Lluvia Editores, Lima)

Giuliani E, 2003, "Knowledge in the Air and its Uneven Distribution: A story of a Chilean Wine Cluster", Druid Winter Conference, Aalborg, http://www.druid.dk/conferences/winter2003/Paper/Giuliani.pdf

Giuliani E, Rabellotti R, Pieter van Dijk M, 2005, Clusters Facing Competition: The Importance of External Linkages (Aldershot, Ashgate) 
Giuliani E, Bell M, 2005, “The micro-determinants of meso-level learning and innovation: evidence from a Chilean wine cluster" Research Policy 34 47-68

Gomes R, 2006, “Upgrading without Exclusion: Lessons from SMEs in Fresh Fruit Producing Clusters in Brazil", in Upgrading to Compete: Global Value Chains, Clusters, and SMEs in Latin America, Eds, C Pietrobelli, R Rabellotti, Inter-American Development Bank, Washington DC

Gray M, Golob E, Markusen A, 1996, "Big Firms, Long Arms, Wide Shoulders: The 'Huband-Spoke' Industrial District in the Seattle Region” Regional Studies 30 651-666

Hargadon AB, 1998, "Firms as knowledge brokers: Lessons in pursuing continuous innovation”. California Management Review 40 209-227

Hojman DE, 2005, "Network Learning, Principal-Agent Conflict and Award-Winning WineMaking in Chile's Colchagua Valley" Research Paper Series No 2005/12, University of Liverpool Management School

Howells J, 2006, "Intermediation and the role of intermediaries in innovation" Research Policy 3, $715-728$

Iizuka M, 2006, “'Low-tech' industry: a new path for development? The case of the salmon farming industry in Chile" Globelics Conference, India, September

Kohl B, 2003, "Non-governmental organizations as intermediaries for decentralization in Bolivia”, Environment and Planning C: Government and Policy, 21, 317-331.

Lave JC, Wenger E, 1991, Situated Learning, Legitimate Peripheral Participation (Cambridge University Press, New York) 
Maggi C, 2003, "El Cluster del Cultivo y Procesamiento del Salmon en la Region Sur-austral de Chile”. AGORA 2000 mimeo for IDB, Rome and Washington

Malmberg A, Power D, 2005, “(How) Do (Firms in) Clusters Create Knowledge”? Industry and Innovation 12, 409-431

Marshall A, 1920, Principles of Economics (Macmillan, London)

McEvily B, Zaheer A, 2004, "Architects of trust: The Role of Network Facilitators in Geographical Clusters. In Trust and Distrust in Organizations: Dilemas and Approaches, K.S. Kramer R.M. Cook, Eds p189-213.

McCormick D, 1999, “African Enterprise Clusters and Industrialization: Theory and Reality"

World Development 27 1531-1551

McDermot G, Corredoira R, Kruse G, 2009, Public-private institutions as catalysts of upgrading in emerging market societies. Academy of Management Journal 52, 1270-1296.

Obstfeld D, 2005, "Social Networks, the Tertius Iungens Orientation and Involvement in Innovation” Administrative Science Quarterly 50, 100-130

Olson M, 1982, The Rise and Decline of Nations (Yale University, New Haven)

Pant LP, Odame HH, Hall A, Sulaiman RV, 2008, "Learning Networks Matter: Challenges to Developing Learning-Based Competence in Mango Production and Post-Harvest in Andhra Pradesh India” UNU-Merit Working Paper Series, No 069

Pietrobelli C, Rabellotti R, 2006, “Upgrading to Compete: Global Value Chains, Clusters, and SMEs in Latin America” Inter-American Development Bank, Washington DC 
Piore MJ, Sabel CF, 1984, The Second Industrial Divide: Possibilities for Prosperity (Basic Books, New York)

Popp A, 2000, "Swamped in information but starved of data: information and intermediaries in clothing supply chains” Supply Chain Management: An International Journal 5 151-161

Porter M, 1990, The Competitive Advantage of Nations (Macmillan, London)

Provan KG, Human SE, 1999, "Organisational learning and the role of the network broker in small-firm manufacturing networks" in Interfirm Networks: Organisation and Industrial Competitiveness, (Routledge, London)

Safford, S 2007, Why the garden club couldn't save Youngstown: Civic Infrastructure and Mobilization in Economic Crises (Cambridge, MA: Harvard University Press)

Sapsed J, Grantham A, DeFillippi R, 2007, “A bridge over troubled waters: Bridging organisations and entrepreneurial opportunities in emerging sectors" Research Policy 36, $1314-1334$

Schmitz H, 1995, "Collective Efficiency: Growth Path for Small-Scale Industry" Journal of Development Studies 31, 529-566

Schmitz H, Nadvi K, 1999, "Industrial Clusters in Developing Countries” World Development (Special Issue) 29 1605-1626

Schmitz H, Knorringa P, 2001, "Learning from Global Buyers" Journal of Development Studies 37, 177-205 
Sengenberger W, Pyke F, 1991, "Small Firm Industrial Districts and Local Economic Regeneration: Research and Policy Issues”, Labour and Society, 16(1), International Labour Organisation

Zuckerman, E Sgourev, S. 2006. Peer capitalism: Parallel relationships in the U.S. economy. American Journal of Sociology, 111 1327-1366.

' Firms can be divided up into firms that produce and export and will be members of the producer association APEM, from those that produce only, who will tend to be member of PROMANGO. APEM members will be bigger and own larger areas of land that members of PROMANGO. A couple of organisations are members of both associations. 